\title{
A STUDY OF THE IMPLEMENTATION OF TEACHING SPEAKING OF PRIMARY SPEAKING CLASS AT SMART ILC PARE KEDIRI
}

\author{
Sutrimo
}

\begin{abstract}
The main objective of this study is to describe how the teaching of Primary Speaking class at SMART ILC. The researcher limits this study only to find and then describe; the implementation, the responses of the students, the result of the students, and the evaluation of the students after joining Primary Speaking class at SMART ILC. This research used descriptive qualitative approach as a research design. The subject was Primary Speaking students. The methods used in collecting data were interview, observation, field note and documentation. The data analysis was based on three concurrent flows of activities, they were: data reduction, data display, and verification. The result of this study shows that syllabus, lesson plan, materials, method, technique, and media of teaching were available. The curriculum was not necessary for non-formal education to have it. The resrponses which came from students were various. They were active, responsive, nervous, but they felt enjoyable. The result of students after joining the class was FAIR. And the evaluation that the students gave according to the documentation was GOOD.
\end{abstract}

Keyword: implementation, speaking, primary speaking

\section{INTRODUCTION}

English has now become very essential language in the world. The students not only can study English at school, but also they can learn English in nonformal education. Here the purpose of non-formal education is to complete, to change, and to add the students' knowledge that they even or never get from formal education. In addition, some people who want to get a job and best education in the future actually take non-formal education to increase their English ability. Non-formal education is very important and has rule to increase quality of education. There are many non-formal educations in Indonesia and one of them that can help the students' English ability ton be improved is English courses.

Technology and globalization in modern life accelerate changes in all fields. An organization or institution must be able to adapt quickly and better in order to survive and not experience destruction. A non-formal education institution can respond to changes and demands for changing times if the organization can quickly read and recognize new conditions and immediately adapt to those changes.

Learning organization for Non-formal is a way to adapt quickly and precisely. Garvin (1993) in Swee C. Goh (1998) states: "A learning organization 
is an organization skilled at creating, acquiring and transferring knowledge, and modifying its behavior to reflect new knowledge and insights" (Sam Advanced Management Journal, 1998). A learning organization is an organization that is skilled in creating, acquiring and transferring knowledge, and modifying behavior to reflect new knowledge and insights. Learning organizations are organizations where people continually expand their capacity to create the results they want.

According to Peter Senge (in Leksana TH, without years) states that there are five pillars that make an organization a learning organization and survivefor longer time:

1. Personal Mastery, which is learning to expand personal capacity in achieving the most desirable work results, and creating an organizational environment that fosters all its members to develop themselves towards achieving the goals and meaning of working in accordance with their chosen expectations.

2. Mental Models, namely the process of reflecting and enhancing our selfimage of the outside world, and seeing how they shape our decisions and actions.

3. Shared Vision, namely building a sense of commitment in a group by developing a shared picture of the future that will be created, principles and practices that guide the way we achieve these future goals.

4. Team Learning, which transforms speech and thinking skills, so that a group can legitimately develop a greater brain and ability than when each group member works alone.

5. Thinking system, which is a perspective, a way of speaking to describe and understand the strengths and relationships that determine the behavior of a system (Learning Organization (c) Strategic Solution Center, www.sscnco.com).

Michael J. Marquardt (2002) in his book Building the Learning Organization states that in learning organizations there are five subsystem elements. Learning subsystems are learning, organization, people, knowledge, and technology. Learning will not be sustainable without understanding and developing the five subsystems. All subsystems must be maintained at the sustainability of the learning organization to achieve organizational success.

Pare has a lot of institutions and courses that offer English learners to learn English language based on what they need, whether it is for getting next study or getting job. Pare offers learners for many English programs, such as Pronunciation, Grammar, and Vocabulary class, also some application programs, such as Speaking, Listening, Reading, Writing, Translation, Pre-TOEFL, TOEFL or even to pass IELTS test. It is also supported by several dormitories and camps which require the members to speak English 24/7 (all the time) to build the atmosphere of English. Speaking class is most favourite program that the learners choose.

To introduce the programs of the institution, each institution competes one another to get the customers. Some institutions chose to promote the programs with modern way (online way by website). It absolutely spend lots of money. And some other institutions prefer to promote the programs with traditional way (to 
visit one school to another school; one person to another one by brochure) in order to spend little outcome. The competition to get customers is not very easy. To give the best service is the best idea to make the previous customers get back to the institution, moreover they could promote it to other people. In fact, satisfaction of the customers after getting taught in the institution is the key of getting heart of people. The institutions, which used the traditional way in promoting its programs, in fact, couldn't stand for longer time. On the contrary, the institutions which used the modern way in introducing its programs could stand because people all over the world can know it.

\section{METHODOLOGY}

The design which was used in this research was a descriptive qualitative study. It was suggested that numerical measures are never used but that other means of description are emphasized. It was chosen cause there was no treatment in this research. Qualitative method was also considered as the most important data collection. It was called descriptive cause it was different from other research like quantitative which focused in specific, detail, and explicit which used measuring statistic. The qualitative method helped in collecting and analyzing the data.

The descriptive qualitative research used private interview, data observation, picture of research subject of observation, and documentations (purpose to all of elements in that course such as students, tutors, and the director of the institution) as the data collection technique. By observing the object of research directly and collecting some pictures of the observation, the description evolved naturally and it can help to describe the whole real condition and situation of the object of the research.

Interview, recording, and observation checklist as the instrument of data descriptive qualitative research are the important thing to analyze the case. The interview and recording related to the research problem gave more information to develop the description cause the interview is purposed to some parties around the case environment who know well about the real case in the field and the observation checklist might need in this research to collect and ensure the data. By using the descriptive qualitative research design, the problems of the research were known well and it found the solving problem.

\section{FINDING AND DISCUSSION Finding}

By using interview and observation on April $10^{\text {rd }} 2018$, the implementation of teaching speaking bprocess of Primary Speaking class consisted of : the syllabus is applied in Primary Speaking class. From the different statement of the sources from syllabus, clarification is needed and the the director and tutors explained that all of the sources are used and they are needed to develop the best syllabus for this program. Revision is also needed every period if there was any new findings about how to teach new students with unusual problem as what had been found by the tutors. Teaching speaking that is done by the tutors used lesson plans, although the form is made by its institution which is certainly different 
from lesson plans in formal schools. The materials used in the teaching process were the whiteboard, markers with four colours, dictionaries and some reference book. Materials were given directly in the class. Primary Speaking class at Smart ILC dint have any handbook for students.. The appropriate technique to teach speaking is the combination between Teacher-centered learning and Studentcentered learning, according to the materials given each meeting.

Evaluation in the learning process is very important, which is useful to find out the extent to which students are able to achieve success in the classroom. In accordance with the interviews that have been conducted with the director, tutors, students, and also the results of observations found that the type of evaluation used in teaching speaking is to use values taken from everyday life and also from tests conducted every day before the program.

\section{Discussions}

The method which was applied in the class was direct and natural method and the student who was in class should answer in English. The students were not allowed to speak Indonesia. According Freeman (2000: 7), there are eight methods of mastering language: 1) Grammar Translation Method, 2) Direct Method, 3) Audio-Lingual Method, 4) Silent Way, 5) Suggestopedia, 6) Total Physical Response Method, 7) Communicative Method, 8) Community Language Learning Method. And 9) Grammar Translation Method . From the observation in the class, it can be concluded that the tutor used direct or natural method in teaching. In the teaching process, interview and discussion technique were used to teach the students. The tutor was selective to use the proper technique to adjust it to the students during the period. It was supported from the questionnaire which was shown that eight students answered sometimes the tutor used different technique in teaching and seven students answered that the tutor seldom to use different technique. According to Crookes and Chaudron (1991) as quoted by Brown (2001: 134-135), there are three broad categories of techniques in language teaching classroom are used: controlled, semi-controlled, and free. From the explanation was known of each technique that interview and discussion were categorized to free technique, it means that Primary Speaking class used free technique to teach students of Primary Speaking class. The media which was used in Primary Speaking class were whiteboard, markers with four colours, dictionaries and some reference book such as Basic English Grammar (Betty Azhar).

\section{CONCLUSION}

This chapter provides the conclusion of the research directed to the subject that involved in the research to upgrade the successful of the implementation of the teaching speaking of Primary Speaking class at SMART ILC. The implementation of the teaching speaking of Primary Speaking class at SMART ILC related to the term of the curriculum, syllabus, lesson plan, materials, method, technique, media, and evaluation of teaching speaking of Primary Speaking class at SMART ILC was good. Because just one point that is not appropriate, that was curriculum, and the others were appropriate, such as syllabus, lesson plan, 
materials, method, technique, media, and evaluation of teaching speaking of Primary Speaking class at SMART ILC.

Based on the findings with the interview and observation, it can be found that there were different responses from the students each meeting. In the observation sheet, When the tutors used Communicative Language Teaching (CLT), Audio Lingual Method (ALM), and Situational Language Teaching (SLT) in the dialogue, or games section, the students were active to communicate and pay attention. When the tutors used Grammar Translation Method (GMT), and Total Physical Responses (TPR) especially in Review time and the Checking, the students were nervous in learning. When the tutors gave the rheory, the students seemed to pay attention very carefully. Besides they were nervous when the tutors reviewed the previous materials because they were afraid to get scratched with marker. But they looked enjoyable with that situation. Based on the finding on the documentation (on the photos), we could find that the Teacher-centered learning and Student-centered learning method were used based on what materials given in the class.

Based on the interview and documentation about the result, it could be found that the learning outcomes of the students during the program in the teaching speaking of Primary Speaking class at SMART ILC were FAIR. This was the evidenced by the value of which was owned by the tutor as well as the title listed on the certificate for each students. Based on the documentation about result, it could be found that there were 5 students who got grade "E" . Four of them, it is because they didn't use to attend the class, so that they didn't have full score (daily test, weekly test, middle test and final examination). One of them, it is because she was a beginner in learning English. It was not easy for her to understand a lot materilals. On the other hand, there were 7 students who got grade "C". They attended the class properly and did exercises well enough. Because they were just beginners in English, it meant that they were good enough in understanding the lesson and applying it in the exercises they got. And there were 4 other students who got gade "B". They attended the class properly and did the exercises well. From the statements above, the result of the students was FAIR.

\section{REFERENCES}

Abdulhak, Ishaq dan Ugi Suprayogi. 2012. Penelitian Tindakan dalam Pendidikan Nonformal. Jakarta: PT Raja Grafindo Persada

Arsyad, A. 2002.Media Pembelajaran.Jakarta: Raja Grafindo Persada.

Brown, H. D. 2001. Teaching by Principles: An Interactive Approach to Language Pedagogy. San Fransisco: Addison Wesley Longman, Inc.

Brown, H. D. 2004. Language Assessment: Principles and Classroom Practices. New York: Longman.

Combleet and Carter. 2001. The Way of Mastering English Language, Cambridge: Cambridge University Press. 217. 
Fattah, Nanang. 2009. Ekonomi dan Pembiayaan Pendidikan. PT. Remaja Rosdakarya, Bandung.

Sudjana, Nana. 2004. Dasar-dasar Proses Belajar Mengajar. Bandung : Sinar Baru Algensido Offset.

Taken from dictionary. 2003. Oxford Learner Pocket Dictionary New Edition. Oxford University Press. 